\title{
DISCOVERIES IN INDIGENOUS TERRITORIES: TWO NEW SPECIES OF LEPANTHES (ORCHIDACEAE: PLEUROTHALLIDINAE) IN SOUTHWESTERN COLOMBIA
}

\author{
Juan Sebastián Moreno ${ }^{1,5}$, Gustavo Adolfo Pisso-Florez ${ }^{2}$ \& Sebastián Vieira-Uribe S $^{1,3,4}$ \\ ${ }^{1}$ Grupo de Investigación Schultes, Fundación Ecotonos, Cali, Colombia \\ ${ }^{2}$ Parque Nacional Natural Puracé, Popayán, Colombia \\ ${ }^{3}$ Sociedad Colombiana de Orquideología, Medellín, Colombia \\ ${ }^{4}$ Grupo de investigación en biodiversidad tropical - GIBIOT, Jardín Botánico de Medellín, Colombia \\ ${ }^{5}$ Author for correspondence: semoreno113@gmail.com
}

\begin{abstract}
Two new species of Lepanthes from the Central Cordillera of the Colombian Andes are described and illustrated. Both were found during a botanical expedition to Puracé National Natural Park, within the high Andean forests ecosystem of the municipality of Puracé, in the department of Cauca.

Resumen. Dos nuevas especies de Lepanthes de la Cordillera Central de los Andes Colombianos se describen e ilustran. Ambas fueron encontradas en una expedición botánica al Parque Nacional Natural Puracé, en Bosques Altoandinos en el municipio de Puracé en el departamento del Cauca.
\end{abstract}

Key Words: Cauca, Colombian Massif, Kokonukos, Paletará, Puracé National Natural Park

Introduction. The National Natural Park (PNN) Puracé and its buffer zone cover areas of Andean, high-Andean forest, and paramo ecosystems in the Colombian Massif of southwestern Colombia. This PNN is located in the southern sector of the Central Cordillera between the departments of Cauca and Huila, it has an extension of 91,483 ha with an elevation range between 2350 and $5000 \mathrm{~m}$ a.s.1. (Bonilla-Valencia et al. 2019). In the northwestern of PNN Puracé, the buffer zone si inhabited by the Kokonukos indigenous community, distributed in the Resguardo of Kokonuko, Puracé, and Paletará, occupying approximately 15,630 ha in the western slope of Cordillera Central, municipality of Puracé, centraleastern area of the Cauca department (Fig. 1) (Bravo 2012). This indigenous community recognizes the vital importance of biodiversity conservation since the geographical sites are intimately linked to its worldview and especially the ancestral medical system, describing their natural territory like the land of "Jucas" that corresponds to an ancestral power of the underground world where water dominates (Faust 1991, 2004).

Given its location, this area occupies a unique position to study the high Andean flora diversity, but this information is scarce and scattered with limited scientific publications (Rangel-Ch \& Lozano-D 1986, Duque \& Rangel-Ch 1989, Duque \& Restrepo 1992, Alzate 2007, Hágsater \& Santiago 2015, Abud \& Torres 2016, Hágsater, Santiago \& Uribe Vélez 2018, Bonilla-Valencia et al. 2019). Here, contributing to the knowledge of the flora in this important area, we describe and illustrate two new Lepanthes Sw. species found within the Kokonukos indigenous territories in the Cauca department of Colombia. The new species were found during a botanical expedition between December 2019 and February 2020, within and in surrounding areas of the Puracé PNN.

\section{Materials and methods}

Descriptions and drawings. - The descriptions and drawings were prepared from living specimens. Specimens were dissected under an AmScope SM1TNZ-144A-3M stereo microscope and preserved in alcohol. Digital images were taken with a Nikon D750 with a Nikkor $105 \mathrm{~mm} \mathrm{f/1.8} \mathrm{macro} \mathrm{lens.} \mathrm{Sketches}$ from living and preserved specimens were digitized, and the images were used for diagramming a draft composite template in Adobe Photoshop ${ }^{\circledR}$ CS6. Then, a digital composite line drawing was made (lines and stippling) in Procreate illustration application for iPad $6^{\text {th }}$ generation tablet computer (Bogarín et al. 2019). 


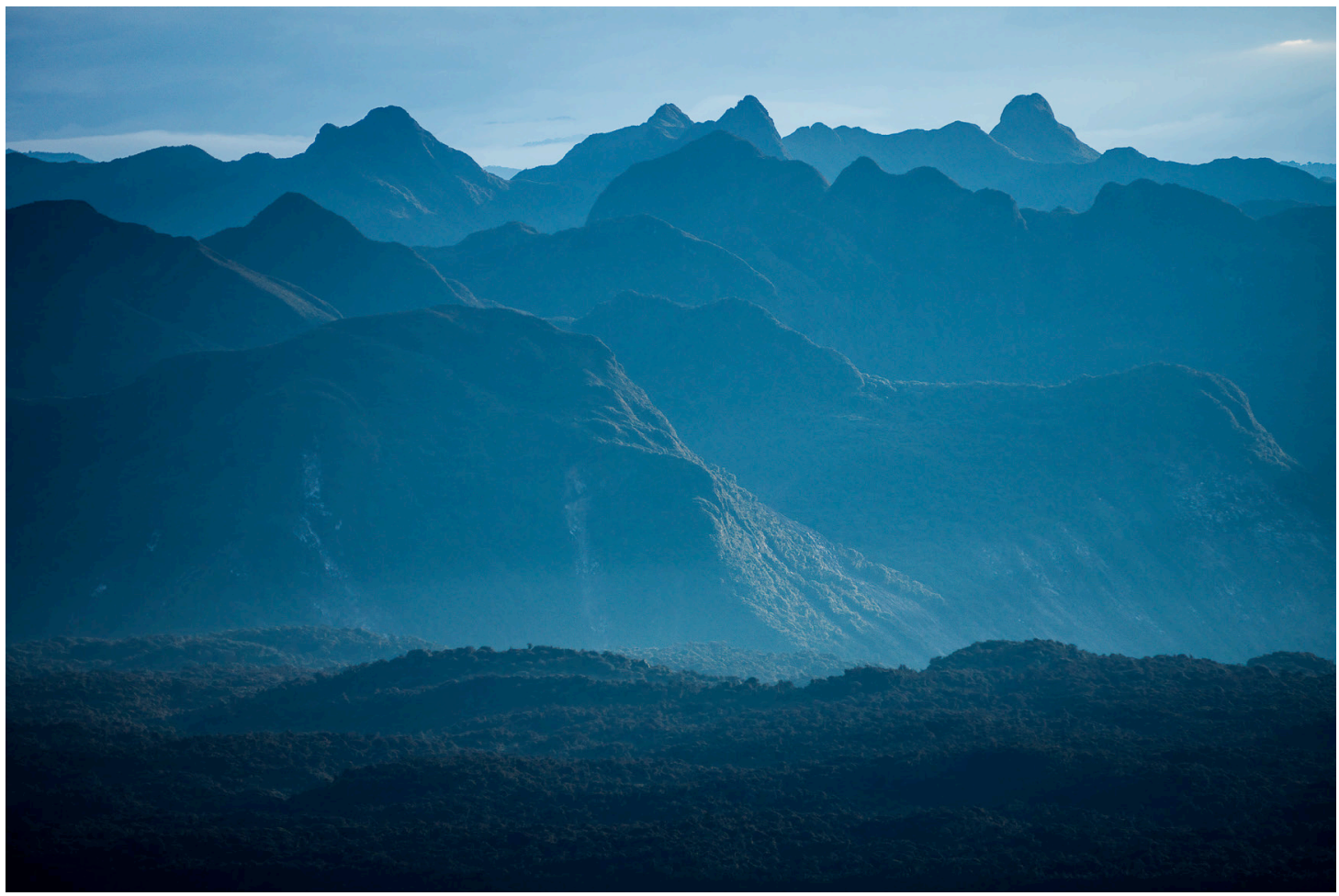

Figure 1. Panoramic view of "Jucas" territories in the "Resguardo Indígena de Puracé” from the Kokonukos volcanic chain, PNN Puracé, southwestern Colombia. Photograph by Diego Miguel Garcés.

Plant material.- Lepanthes specimens in the following herbaria AMES, CAUP, ICESI, JAUM, HPUJ, HUA, FMB, VALLE, JBB, CUVC, SEL, MO (online), TOLI and COL (online) were consulted, but no additional material was found there for us to include in the description of the new species.

\section{TAXONOMIC TREATMENT}

Lepanthes kokonuko J.S.Moreno \& Pisso-Florez, sp. nov. (Fig. 2-3, 6A).

TYPE: COLOMBIA. Cauca: Municipality of Puracé, Cabildo indígena de Paletará, Río Negro village, 3235 m. February 2020. J .S. Moreno, A. L. Erazo, G. Pisso 523 (holotype: CAUP!).

Diagnosis: Lepanthes kokonuko is most similar to Lepanthes guanacasensis Luer \& R.Escobar, but it can be distinguished by its strongly ovate revolute lateral sepals ( $v s$. ovate, non-revolute), its transversely bilobed petals with the upper lobe lanceolate (vs. oblong) and a bilaminate lip with the blades microscopically pubescent (vs. essentially glabrous) and a bipartite appendix with two linear clavate processes (vs. ovoid appendix minutely bilobulate at the apex).

Plant epiphytic, medium in size, caespitose, erect to suberect, up to $11.5 \mathrm{~cm}$ tall. Roots slender, flexuous, filiform, $c a .1 \mathrm{~mm}$ in diameter. Ramicauls slender, erect to suberect, stout, up to $8 \mathrm{~cm}$ long, enclosed by 2-6 lepanthiform sheaths, furrowed, microscopically ciliate along the margins, with a dilated ostia, acuminate. Leaves erect, coriaceous, elliptical, acute, the apex emarginate with an abaxial apiculum in the middle, $1.5-3.5 \times 1.0-1.5 \mathrm{~cm}$, the base cuneate contracted into a petiole $4-6 \mathrm{~mm}$ long. Inflorescence 2-3 congested, successively few-flowered racemes up to $7 \mathrm{~cm}$ long including the peduncle, loose, distichous, flexuous positioned below the leaf by a filiform peduncle up to $2.5 \mathrm{~cm}$ long; floral bract deltoid, acute, 1.5-3.6 mm long; pedicel terete, persistent, 3-4 mm long. Ovary with 3 fringed wings, costate, $1.0-1.3 \mathrm{~mm}$ long. Flowers with sepals light yellow, the lateral medially suffused 


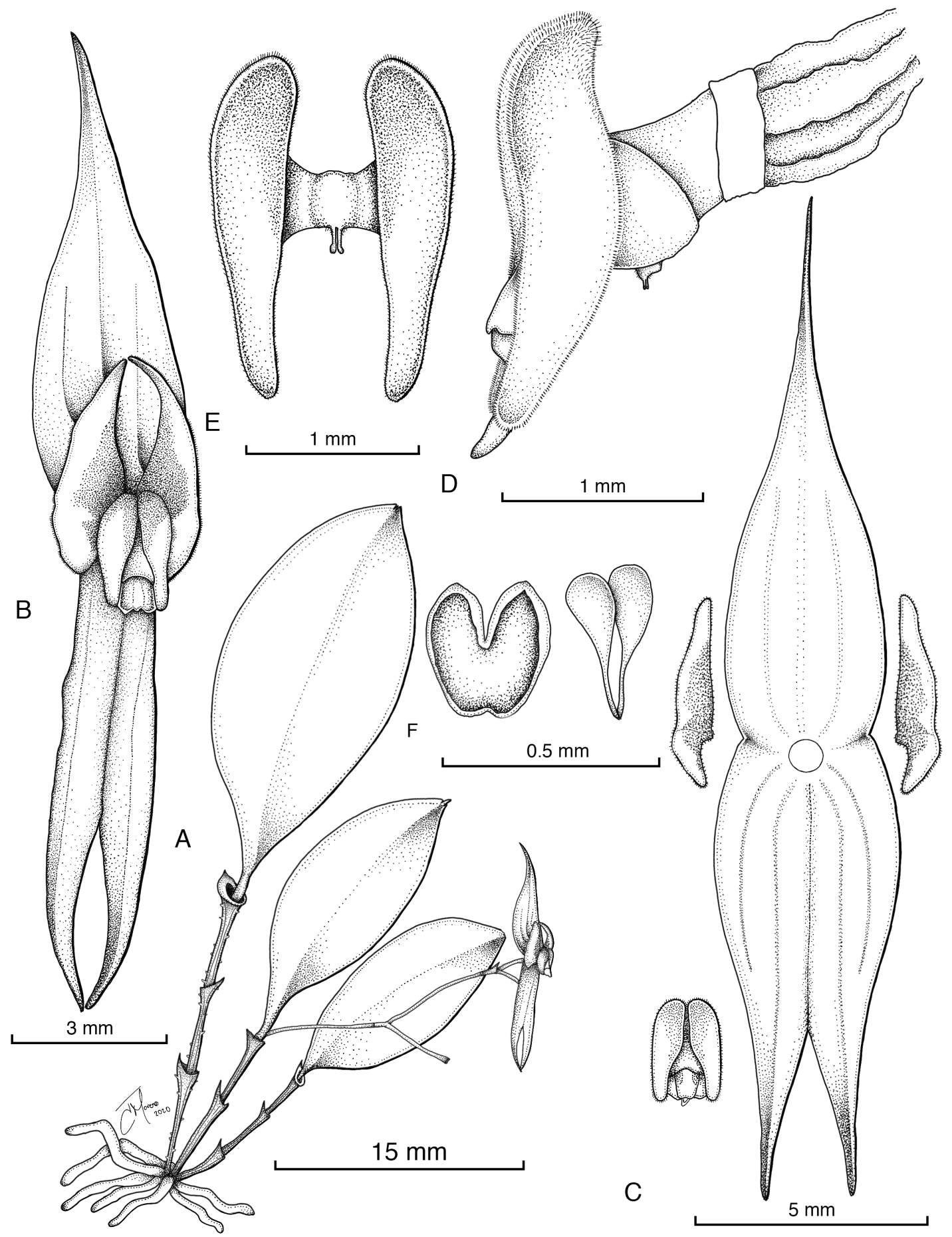

FiguRe 2. Lepanthes kokonuko J.S.Moreno \& Pisso-Florez. A. Habit. B. Flower. C. Dissected perianth. D. Lip, column and ovary, lateral view. E. Lip, adaxial view. F. Pollinia and anther cap. Drawn by J. S. Moreno from J. S. Moreno \& A. L. Erazo 523 (CAUP). 

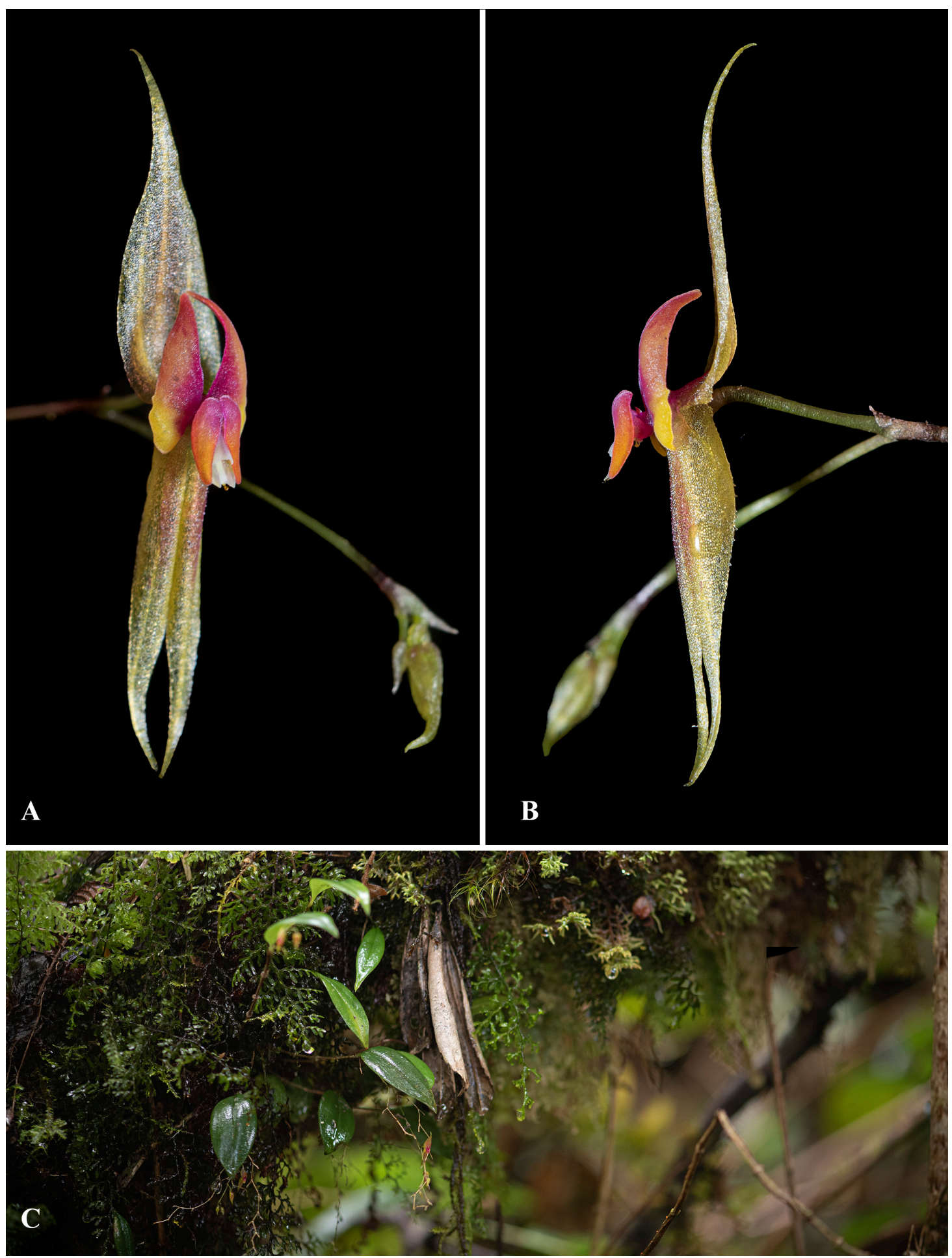

Figure 3. Lepanthes kokonuko J.S.Moreno \& Pisso-Florez. A. 3/4 view. B. Lateral view. C. Habit and plant, in-situ. Photographs by J. S. Moreno of the plant that served as type. 
with burgundy, petals yellow with the upper lobes suffused with burgundy towards the base and orange along the margins, lip saffron marginally suffused with orange, the base of the blades crimson, column white, anther cap pink. Sepals similar in shape and size, ovate, attenuate, carinate abaxially along the veins. Dorsal sepal 3-veined, slightly concave, 1.0 $1.3 \times 0.3 \mathrm{~cm}$, connate to the lateral sepals for $2 \mathrm{~mm}$. Lateral sepals 2 -veined, strongly revolute in natural position, $1.0 \times 0.4 \mathrm{~cm}$, connate for $6 \mathrm{~mm}$. Petals microscopically pubescent, transversely bilobed, with a small, marginal angle between the lobes, $1.0 \times 4.5$ $5.0 \mathrm{~mm}$, the upper lobe narrowly triangular, acute, recurved, $3.0-3.5 \mathrm{~mm}$ long, the lower lobe ovate to triangular, slightly falcate, acute, with a retuse inner margin, $1.0-1.5 \mathrm{~mm}$ long. Lip bilaminate, the blades ovate-lanceolate with rounded ends, microscopically pubescent, $2 \times 1 \mathrm{~mm}$ long, the connectives cuneate, the body, connate to the base of the column, the sinus broad with a bipartite appendix composed of two linear, clavate processes. Column terete, $1.5 \mathrm{~mm}$ long, the anther dorsal and the stigma apical. Anther cap orbicular to cordate, cucullate, $0.25 \mathrm{~mm}$ wide. Pollinia yellow, two, pyriform, $0.3 \mathrm{~mm}$ long.

PARATYPE: COLOMBIA. Cauca: Municipality of Sotará, Piedra León village, 3172 m. March 2020. J. S. Moreno, A. L. Erazo, G. Pisso 524 (Paratype: CAUP!).

Eтymology: The name Kokonuko, which means "Mountain people", refers to the Kokonukos indigenous community that inhabit the area where the species was found. Also, in reference to the Kokonukos volcanic chain, a sacred place protected by the Puracé National Natural Park and its local communities.

Distribution AND ECOLOGY: Lepanthes kokonuko is found in the Colombian Massif of the western slope in Central Andes at Piedra León village in the municipality of Sotará and Rio Negro village in the municipality of Puracé, both in the Cauca department, between 3172$3235 \mathrm{~m}$ in elevation (Fig. 4). It has been found growing as an epiphyte next to Lepanthes cyrtostele Luer \& Hirtz, Lepanthes mucronata Lindl., and Lepanthes arbuscula Luer \& R.Escobar, in a high Andean forest (Fig. 5) with arboreal species like Clusia multiflora Kunth and Weinmannia pubescens Kunth. We observed this species flowering during our visits (December to February), typically dry seasons in that region.
Lepanthes kokonuko can be easily recognized by its caespitose medium size plants, elliptical coriaceous leaves, long loosely, flexuous and distichous inflorescences; strongly revolute lateral sepals, transversely bilobed petals with the upper lobe lanceolate (hornlike), and a bilaminate lip with the blades ovoid-lanceolate with a bipartite appendix. It is probably related to the other racemose species Lepanthes biloba Luer \& R.Escobar, Lepanthes guanacasensis Luer \& R.Escobar, Lepanthes muscula Luer \& R.Escobar and Lepanthes osiris Luer \& R.Escobar (Luer \& Thoerle 2012). The most similar species is undoubtedly Lepanthes guanacasensis (Fig. $6 \mathrm{~B})$, characterized also by its long loosely and flexuous inflorescences like L. kokonuko, ovate dorsal and lateral sepals ( $v s$. strongly revolute lateral sepals) transversely bilobed petals with the upper lobe oblong [vs. lanceolate (hornlike)] longer than the lower lobe and an ovoid appendix, minutely bilobulate at the apex ( $v s$. bipartite with two linear clavate processes). Lepanthes osiris is also similar but it has ovate lateral sepals ( $v s$. strongly revolute lateral sepals), narrowly ovate, subequal petals ( $v s$. upper lobe longer than the lower, the upper lobe lanceolate and the lower lobe triangular) and a lip with a small, oblong, bifid appendix (vs. bipartite with two linear clavate processes). Finally, Lepanthes biloba and Lepanthes muscula have a bilaminate lip with the blades elliptical or ovate, convex in L. biloba and blades oblong in L. muscula (vs. ovate-lanceolate), and both having an orbicular appendix with a pair of rounded terminal lobules ( $v s$. bipartite with two linear clavate processes).

Lepanthes jucas J.S.Moreno \& S.Vieira-Uribe, sp. nov. (Fig. 7-8, 9D).

TYPE: COLOMBIA. Cauca: Municipality of Puracé, Corregimiento de Paletará, road to San José de Isnos, Huila. 3172 m. December 2019. J. S. Moreno, A. L. Erazo, G. Pisso 526 (holotype: CAUP!).

Diagnosis: Lepanthes jucas is similar to Lepanthes cornualis Luer \& R.Escobar, but can be easily distinguished by its elliptical-lanceolate leaves ( $v s$. narrowly elliptical); strongly papillose petals ( $v s$. minutely pubescent, shortly papillose), transversely bilobed with falcate, triangular lobes (vs. lobes narrowly triangular) and bilaminate lip with the blades 


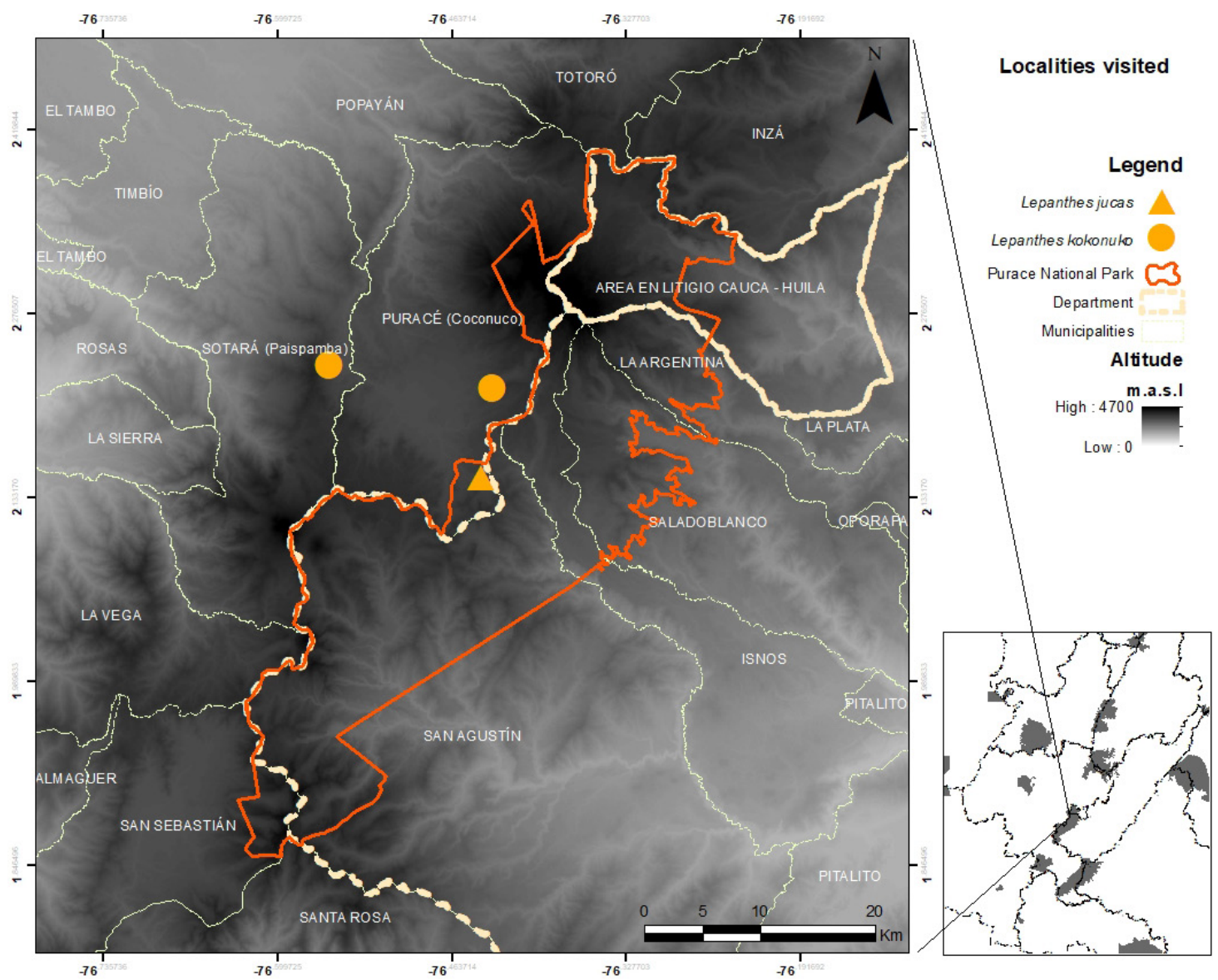

FiguRE 4. Distribution map of Lepanthes kokonuko J.S.Moreno \& Pisso-Florez and Lepanthes jucas J.S.Moreno \& S.VieiraUribe. Circles: L. kokonuko, triangle: L. jucas. Map by G.A. Pisso-Florez.

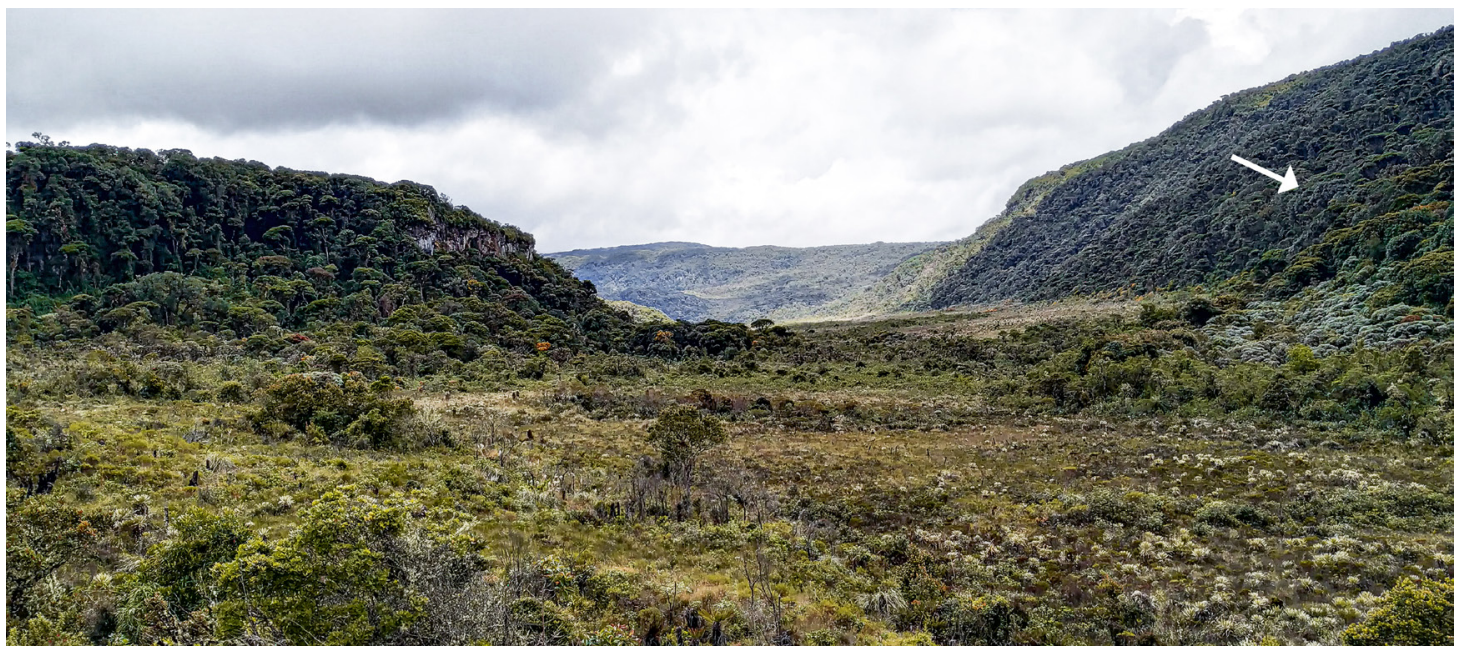

FiguRE 5. High Andean ecosystem where Lepanthes kokonuko J.S.Moreno \& Pisso-Florez was found. Photograph by J.S.

Moreno. 

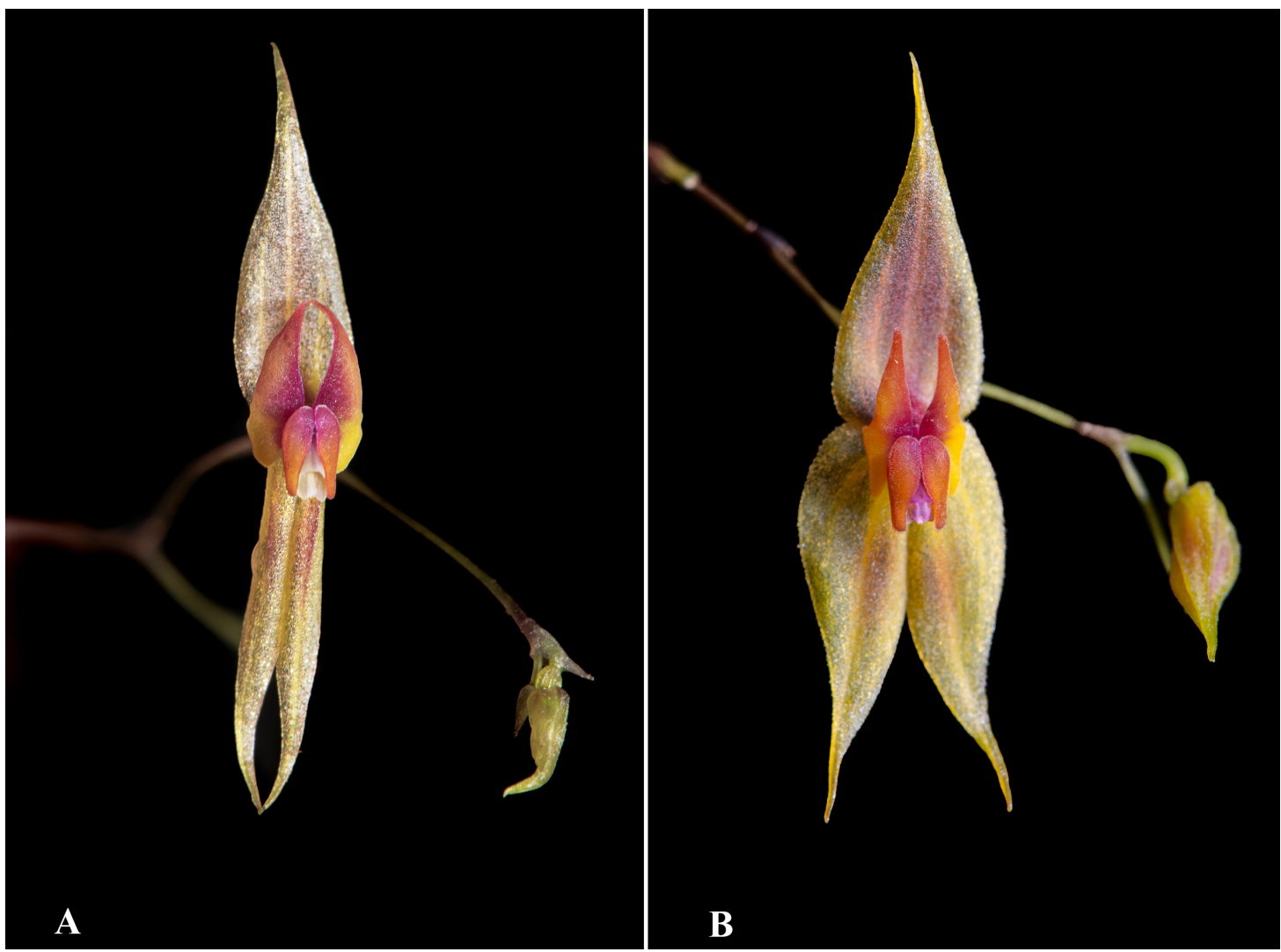

Figure 6. Comparison with the most similar species. A. Lepanthes kokonuko. B. Lepanthes guanacasensis. Photographs by J. S. Moreno.

hispid, obovate to oblong with an ovate appendix (vs. narrowly obovate blades and a minute bilobed appendix).

Plant epiphytic, caespitose, suberect, up to $7.5 \mathrm{~cm}$ tall. Roots slender, $0.5 \mathrm{~mm}$ in diameter. Ramicauls slender, erect to suberect, stout, $2.8-4.2 \mathrm{~cm}$ long, enclosed by 5-8 lepanthiform sheaths, furrowed, with a dilated ostia, acuminate. Leaves erect, coriaceous, elliptical, with slightly revolute margins of the blade, acute, the apex emarginate with an abaxial apiculum in the middle, $2.8-3.2 \times 0.5-0.8 \mathrm{~cm}$, the base cuneate contracted into a petiole 3-4 mm long. Inflorescence subcongested, 1-2 successively flowered racemes up to $2 \mathrm{~cm}$ long including the peduncle, loose, distichous, flexuous, positioned below the leaf by a filiform peduncle up to $1 \mathrm{~cm}$ long; floral bract, acute, $1.0-1.3$ $\mathrm{mm}$ long; pedicel terete, persistent, $3 \mathrm{~mm}$ long. Ovary costate, trialate, with 3 fringed wings, 2 lateral and 1 dorsal, $2 \mathrm{~mm}$ long. Flowers with sepals vinaceous, petals scarlet, lip peach, column scarlet, anther cap pink. Sepals similar in shape and size, ovate, minutely denticulate, attenuate to acuminate, carinate on the abaxial surface along the veins. Dorsal sepal 3-veined, concave, $6.0 \times 3.8-4.0 \mathrm{~mm}$, connate to the lateral sepals for $1.5 \mathrm{~mm}$. Lateral sepals 1-veined, oblique, 5.8-6.0 $\times 4.5 \mathrm{~mm}$, connate for $3 \mathrm{~mm}$. Petals falcate, strongly papillose, transversely bilobed, $1.0-1.3 \times 3.8-4.0 \mathrm{~mm}$, the lobes triangular, oblique, obtuse, the upper lobe wider than the lower lobe. Lip bilaminate, the blades hispid, obovate to oblong, with rounded ends, $2.5 \times 1.0$ $\mathrm{mm}$ long, the connectives short, cuneate, puberulous, the body connate to the base of the column, the sinus obtuse, with an ovate, pubescent appendix. Column terete, slender, $2.5 \mathrm{~mm}$ long, the anther dorsal and the stigma apical. Anther cap cordate, cucullate, $0.5 \mathrm{~mm}$ wide. Pollinia yellow, two, pyriform, $0.5 \mathrm{~mm}$ long.

Additional material examined: COLOMBIA. Valle del Cauca: Municipality of Cali, PNN Farallones, 

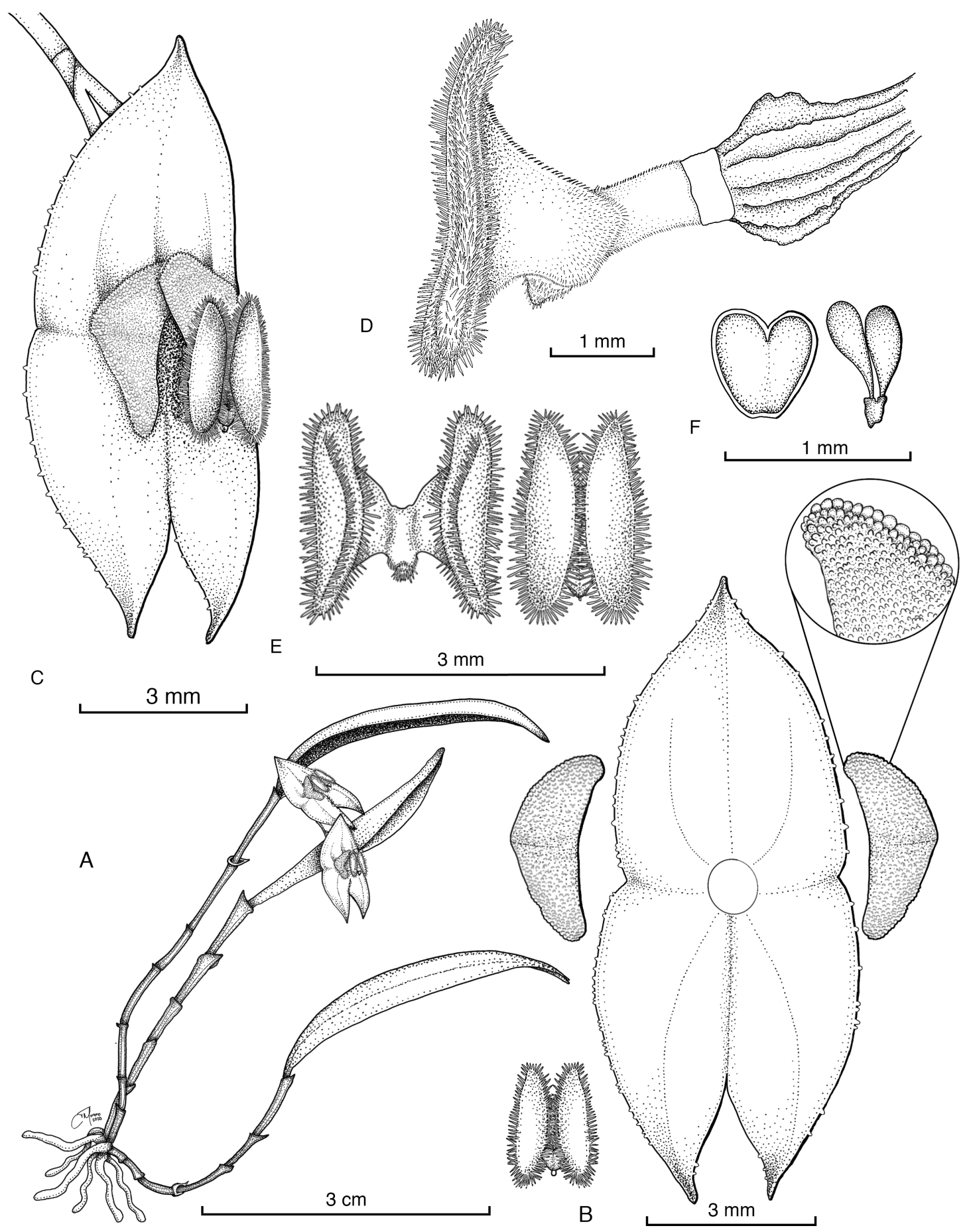

Figure 7. Lepanthes jucas J.S.Moreno \& S.Vieira-Uribe. A. Habit. B. Flower. C. Dissected perianth. D. Lip, column and ovary, lateral view. E. Lip, adaxial view. F. Pollinia and anther cap. Drawn by J. S. Moreno from J. S. Moreno \& A. L. Erazo 526 (CAUP). 
Minas del Socorro. $3231 \mathrm{~m}$. July 2020. R. Galindo-T, A. Fierro, G. Rodriguez, M. Espitia y G. Marín 1468 (CUVC).

Etymology: The specific epithet Jucas represents, for the Kokonukos indigenous communities, an ancestral energy of the underground world where the water dominates. Jucas also means all the native plants, animals and the spirits of nature, even the spirits that cause "mal viento" (cold wind) producing weakness in children and pregnant women. The following description was published by Faust (2004) which states: "From Jucas is the virgin land, the water and all places rich in water as the lagoons, rivers, swamps, primary forests, hills and mountains that "gushes" out water, and even the volcanos that according to the indigenous people of the Colombian Massif, when are snowy "gushes" ice".

DistRIBUTION AND ECOLOGY: Lepanthes jucas was found growing next to Lepanthes caudata Luer \& R.Escobar, in the Colombian Massif of the western slope of the Central Andes on the road between Paletará and San José de Isnos municipalities in the departments of Cauca and Huila, respectively. It has been found on the edge of an open road surrounded by a High Andean Forest Ecosystem within the Puracé National Natural Park. The new species is possibly distributed all along the open road to Huila department where the ecosystem ends (Fig. 4).

Lepanthes jucas belongs to the section Lepanthes subsection Breves, characterized by having one single vein in the lateral sepals (Luer \& Thoerle 2012). It can be recognized by its caespitose plants with ellipticallanceolate leaves, short inflorescences and dark vinaceous flowers with striking papillose transversely bilobed petals and a bilaminate lip with hispid blades. Three species from the subsection Breves share similar traits with Lepanthes jucas. Lepanthes cornualis Luer \& R.Escobar, Lepanthes cyrtostele Luer \& Hirtz (Fig. 9) (Luer 1996), and Lepanthes monoptera Lindl. All of these species might belong to an informal group of species confined to wet and mossy high Andean forests, paramo and subparamo ecosystems from the Andes. The most similar species is Lepanthes cornualis, but it can be distinguished by its petals narrowly triangular, minutely pubescent and shortly papillose along the
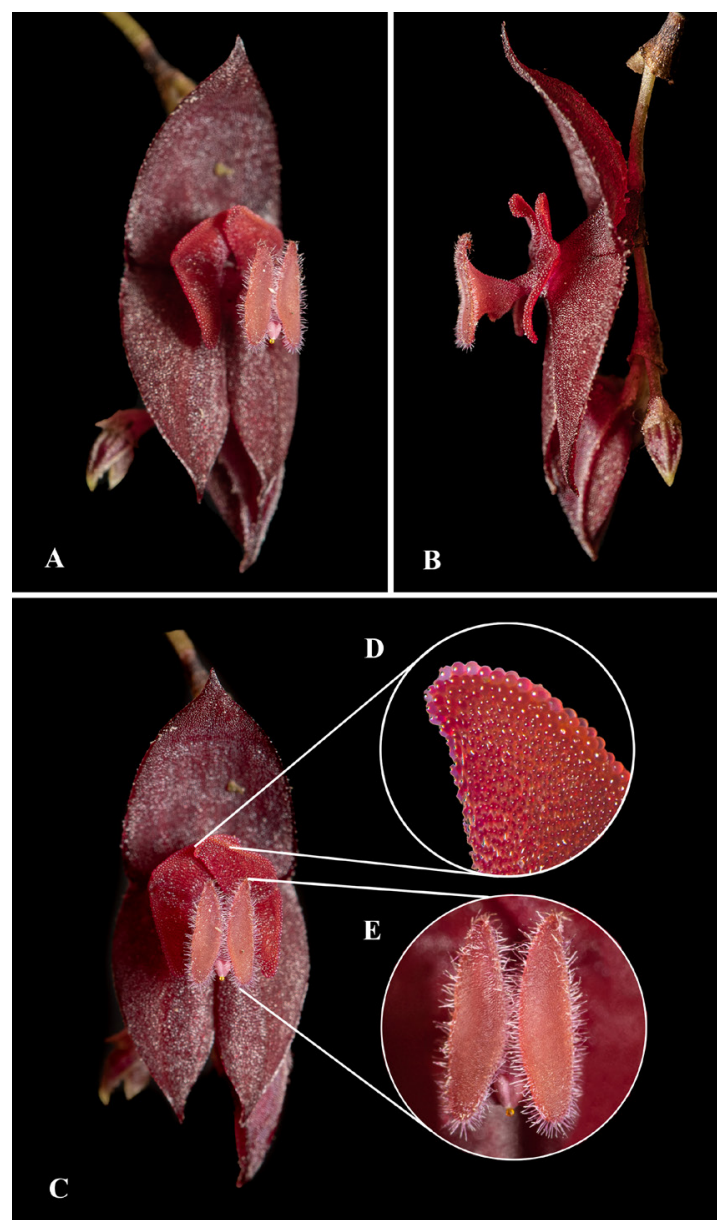

Figure 8. Lepanthes jucas J.S.Moreno \& S.Vieira-Uribe. A.

$3 / 4$ view. B. Lateral view. C. Frontal view. D. Close up of the strongly papillose petals. E. Close up of the long ciliate blades of the lip. Photographs by J.S. Moreno.

margins ( $v s$. falcate, triangular, entire, and strongly papillose), the lip blades narrowly obovate, ciliate with the apices recurved (hornlike) and a minute bilobed appendix ( $v s$. lip blades obovate to oblong, hispid with the apices rounded and an ovate appendix).

These two new species that honor the ancient territories of the Kokonokus indigenous communities within the PNN Puracé and its surroundings are part of a contribution to recognize the native indigenous population in Colombia, its worldview, and its territories. Lepanthes kokonuko and L. jucas are distributed on territories where the forests are still pristine, with numerous lagoons, swamps, volcanos, and surrounded by different paramos that produce big 

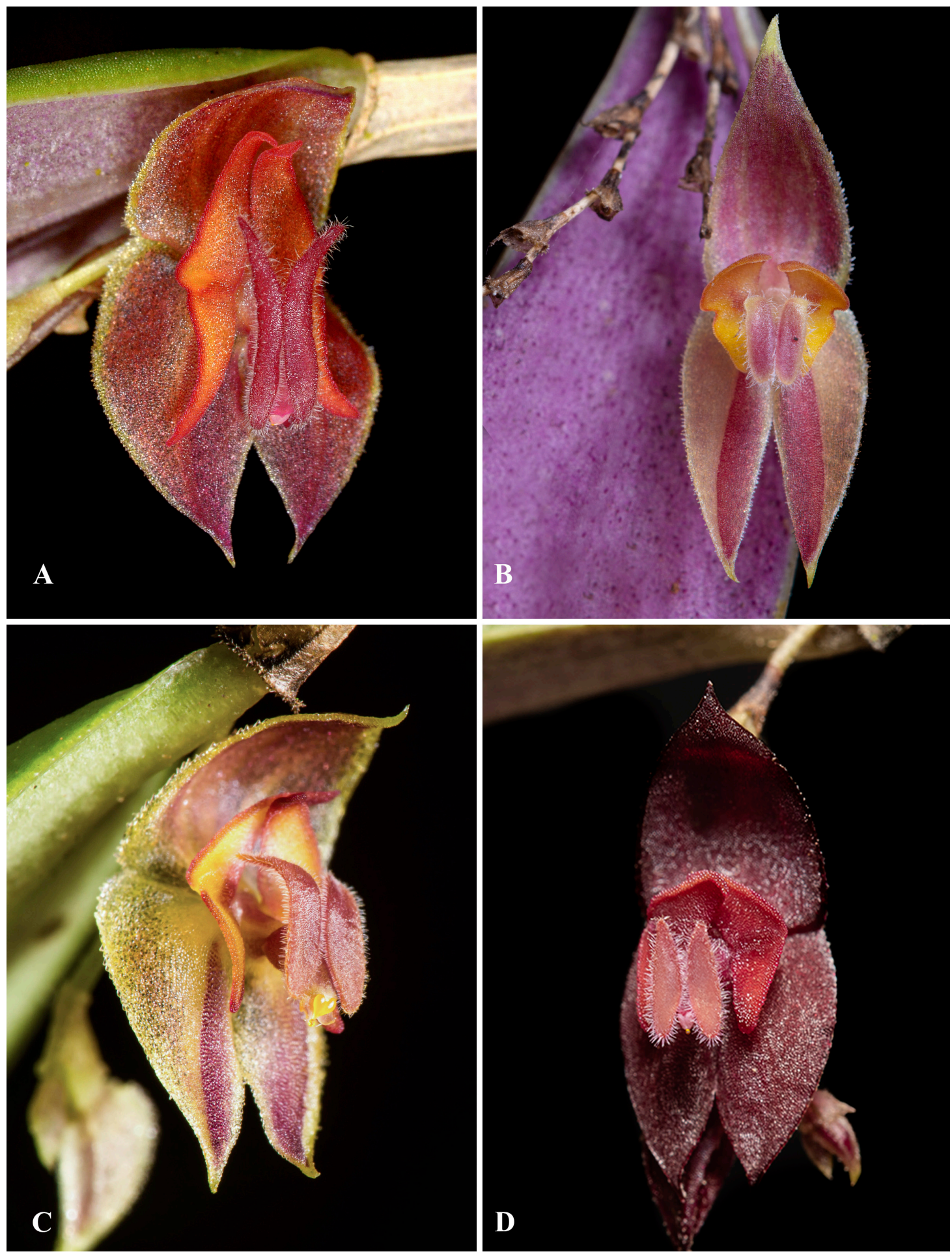

FIgURE 9. Comparison with the most similar species. A. Lepanthes cornualis. B. Lepanthes cyrtostele. C. Lepanthes monoptera. D. Lepanthes jucas. Photographs by Ron Parsons (A) and J. S. Moreno (B-D). 
amounts of water for the human being in Colombia. The ancient territories must be protected all along the country, and conservation efforts must be carried out involving local people to be immersed in biodiversity and conservation actions.

ACKNOWLEDGMENTS. We are grateful with the support of Parques Nacionales Naturales de Colombia and Parque Nacional Natural Puracé, specifically, the chief Isaac Bedoya, who motivated us to develop this research through the contract $087-04$ February 2020, to contribute to the knowledge of the biodiversity of this protected area; and the park ranger Diomar Castro Fierro and son for joining us. To Salomón Avirama and Edgar Pizo, for protecting these high Andean forests where the species were found and for letting us explore their territories. Finally, we thank Kanchi Gandhi from the AMES herbarium at Harvard, for his kind help with the etymologies of the names; to Eugenio Restrepo, for his comments regarding the identity of these new species; to Ron Parsons, who let us use the photograph of Lepanthes cornualis. Finally, to Diego Miguel Garcés, who was very kind in contributing his picture of the volcanic chain of the Kokonukos.

\section{LiTERATURE CITED}

Abud, M. \& Torres, A. (2016). Caracterización florística de un bosque altoandino en el Parque Nacional Natural Puracé, Cauca, Colombia. Boletín Científico Centro de museos de historia natural de la Universidad de Caldas, 20(1), 27-39.

Alzate, F. (2007). Bomarea puracensis (Alstroemeriaceae), a new species from Colombia. Harvard Papers in Botany, 11(2), $125-127$.

Bogarín, D, Eberhard, K \& Díaz-Morales, M. (2019). Lepanthes elusiva - a New Species of Lepanthes (Orchidaceae: Pleurothallidinae) from Tapantí Area in Cartago, Costa Rica and a Glance to Other Species of the Genus in a Small Area Around the Río Grande de Orosi in Costa Rica. Die Orchidee, 5(03), 17-28.

Bonilla-Valencia, J., Roncancio-Duque, N \& Pisso-Florez, G. A. (2019). Portafolio de proyectos de investigación del Parque Nacional Natural Puracé. Documento adjunto al Plan de manejo 2020-2024 del PNN Puracé. Popayán-Cauca: Dirección Territorial Andes Occidentales, Parques Nacionales Naturales de Colombia, 58 pp.

Bravo, N. (2012). La autoridad territorial ambiental indígena y el caso del Parque Nacional de Puracé en el departamento del Cauca, Colombia. En: R. Díaz, M. Pereira \& N. Bravo (eds.), Experiencias organizativas hacia la gobernanza indígena de las áreas protegidas (pp. 45-60). [s.1.]: Grupo Intercultural Almáciga.

Duque, N. \& Rangel -Ch., J.O. (1989). Análisis fitosociológico de la vegetación paramuna del Parque Nacional Natural Puracé. En: L. F. Herrera, R. D. Drennan \& C. A. Uribe (eds.), Cacicazgos prehispánicos del valle de La Plata, Tomo 1. El contexto medioambiental de la ocupación humana. University of Pittsburgh: Latin American Archaeology Publications.

Duque, A. \& Restrepo, C. (1992). Tipos de vegetación del llano de Paletará: cordillera Central Colombia. Caldasia, 17(1), 21-34.

Faust, F. (1991). La cultura de los indígenas del Macizo Colombiano y la protección de la naturaleza en el Parque Nacional de Puracé. Novedades Colombianas, Museo de Historia Natural de la Universidad del Canca, 3, 54-62.

Faust, F. X. (2004). La cosmovisión de los Kokonukos y los Yanaconas en su arquitectura. Boletín de Antropología Universidad de Antioquia, 18(35), 350-360.

Hágsater, E. \& Santiago, E. (2015). Epidendrum erikae Hágsater et E.Santiago, sp. nov. (pl. 1521). In: E. Hágsater \& L. Sánchez Saldaña, L. (eds.), Icones Orchidacearum, fascicle 15(1). The genus Epidendrum part 11. México: Herbario AMO.

Hágsater, E., Santiago, E. \& Uribe Vélez, C. (2018). Epidendrum coconucoënse Hágsater, E.Santiago \& Uribe Vélez sp. nov. In: E. Hágsater \& E. Santiago (eds.), Icones Orchidacearum, fascicle 16(1). The genus Epidendrum part 12. México: Herbario AMO.

Luer, C.A. (1996). Icones Pleurothallidinarum XIV: The genus Lepanthes, subgenus Lepanthes in Ecuador. Monographs in Systematic Botany from the Missouri Botanical Garden, 61, 1-255.

Luer, C. A. \& Thoerle, L. (2012). Icones Pleurothallidinarum XXXII. Lepanthes of Colombia (Orchidaceae). Monographs in Systematic Botany from the Missouri Botanical Garden, 123, 1-296.

Rangel-Ch., R. \& Lozano-C., G. (1986). Un perfil de vegetación entre La Plata (Huila) y el volcán Puracé. Caldasia, 14(68-70), 503-547. 
